\title{
Lena River delta formation during the Holocene
}

\author{
D. Bolshiyanov ${ }^{1,2}$, A. Makarov ${ }^{1,2}$, and L. Savelieva ${ }^{2}$ \\ ${ }^{1}$ State Research Center, Arctic and Antarctic Research Institute, St.Petersburg, Russia \\ ${ }^{2}$ St.Petersburg State University, St.Petersburg, Russia
}

Correspondence to: D.Bolshiyanov (bolshiyanov@aari.ru), A. Makarov (makarov@aari.ru), and L. Savelieva (savelieval@mail.ru)

Received: 31 January 2013 - Published in Biogeosciences Discuss.: 14 March 2014

Revised: 12 October 2014 - Accepted: 30 October 2014 - Published: 29 January 2015

\begin{abstract}
The Lena River delta, the largest delta of the Arctic Ocean, differs from other deltas because it consists mainly of organomineral sediments, commonly called peat, that contain a huge organic carbon reservoir. The analysis of delta sediment radiocarbon ages showed that they could not have formed as peat during floodplain bogging; rather, they accumulated when Laptev Sea water level was high and green mosses and sedges grew and were deposited on the surface of flooded marshes.

The Lena River delta formed as organomineral masses and layered sediments accumulated during transgressive phases when sea level rose. In regressive phases, the islands composed of these sediments and other, more ancient islands were eroded. Each new sea transgression led to further accumulation of layered sediments. As a result of alternating transgressive and regressive phases, the first alluvial-marine terrace formed, consisting of geological bodies of different ages. Determining the formation age of different areas of the first terrace and other marine terraces on the coast allowed the periods of increasing (8000-6000 BP (years before present), 4500-4000, 2500-1500, and 400-200 BP) and decreasing $(5000,3000$, and $500 \mathrm{BP})$ Laptev Sea levels to be distinguished in the Lena Delta area.
\end{abstract}

\section{Introduction}

Until now the geomorphological structure of the Lena River delta has been most fully explained by the scheme proposed by Grigoriev (1993), who distinguished three terraces above the delta floodplain; the third terrace is composed of ice complex rocks, the second terrace is composed of Arga-MuoraSise Island sands, and the first terrace to the floodplain is composed of silt and sand, enriched to varying degrees in plant remains which have often completely displaced the mineral part. Subsequent researchers in the delta proceeded from this scheme, presuming that the delta was a fluvial formation (Schwamborn et al., 2000; Schirrmeister et al., 2003). Geological and geomorphological studies by the authors (Bolshiyanov et al., 2013) showed that all delta terraces were not formed as deposits made by the flooding river. i.e. river terraces; rather, they were formed by Laptev sea-level fluctuations over a long period of time.

The aim of this paper is to elucidate the structure of the first Lena River delta terrace. This structure reflects sealevel fluctuations that resulted in periods of delta erosion alternating with periods of delta development during which organomineral sediments preferentially accumulated.

\section{Study area}

The Lena River delta is the largest Arctic delta with an area of about $29630 \mathrm{~km}^{2}$ (Bolshiyanov et al., 2013). It has a significant impact not only on the Laptev Sea regime, but also on the entire Arctic Ocean due to fresh river water discharge to the smallest and least saline of the Earth's oceans. The delta was formed by the accumulation of sediments from the river and from the erosion and abrasion of ancient landforms due to sea-level fluctuations and the tectonic movements of the Earth's crust. The huge fan-shaped delta extends for $190 \mathrm{~km}$ from north to south $\left(72.0-73.8^{\circ} \mathrm{N}\right)$ and for $250 \mathrm{~km}$ from west to east $\left(122.0-129.5^{\circ} \mathrm{E}\right)$. The length of the entire delta coastline, from the Olenek channel mouth to the Bykovskaya channel mouth, is about $1930 \mathrm{~km}$.

The climate in the Lena River delta area is Arctic continental, characterised by a mean annual air temperature of 
$-13^{\circ} \mathrm{C}$, a mean January temperature of $-32^{\circ} \mathrm{C}$, a mean July temperature of $+6.5^{\circ} \mathrm{C}$, and annual rainfall of $190 \mathrm{~mm}$. The delta is underlain by continuous permafrost $500-600 \mathrm{~m}$ thick. The active (annually thawed) layer is $30-50 \mathrm{~cm}$ thick. The entire delta lies in the tundra zone except for the southern part where the Tit-Ary Island is located. There is a north limit of larch distribution which extended to a latitude of $72^{\circ} 12^{\prime} \mathrm{N}$ in 2006.

\section{Methods}

The primary method used in this study was geomorphological mapping, accompanied by a simultaneous study of the geological and geocryological delta structure. During 2000-2008, geomorphological maps were compiled for different delta areas (Bolshiyanov et al., 2013), and in 2009 the geomorphological map of the entire delta was compiled (Makarov, 2009). The mapping process consisted of direct field measurements of the altitude of various delta terraces, compiling descriptions of terrace microrelief, and deciphering the relief shown in aerial photographs. After the terrace sediments were sampled and radiocarbon dated, the relief elements distinguished in the compiled maps were assigned ages. The geological structure of the islands and the coast were studied by geologically describing key sections exposed by river erosion and sea abrasion. Samples for radiocarbon dating, spore-pollen analysis, and analysis of the plant macroremains from the organomineral masses that make up the islands were taken from these key sections. Holocene marine terraces in the delta area were also investigated and dated. Radiocarbon dating was carried out in the geochronology laboratory at St. Petersburg State University, and the results are presented below. The liquid scintillation method was used for ${ }^{14} \mathrm{C}$ dating as described by Arslanov et al. (1993). Radiocarbon dates are reported throughout the text as uncalibrated ages.

Pollen analyses were carried out at St. Petersburg State University. Peat samples were prepared according to the alkaline method of von Post described by Grichuk and Zaklinskaya (1948). Pollen and spores were identified at magnifications of $400 \times$ with the aid of published pollen keys and atlases (Kupriyanova and Alyoshina, 1972, 1978; Moore et al., 1991) and a modern pollen reference collection at St. Petersburg State University. About 400 terrestrial pollen grains per sample were counted and used for percentage calculations of each identified taxon. The Tilia and Tilia-Graph software (Grimm, 1991) was used for calculating pollen percentages and for drawing the pollen percentage diagram.

Peat samples for botanical analysis were carefully flushed with water through a $0.10-0.25 \mathrm{~mm}$ aperture sieve until the flushing water was completely clear. Plant fibers thus obtained were put on a large glass slide $(9 \times 6$ or $9 \times 12 \mathrm{~cm})$, mixed with a little water, dispersed in a thin layer, and examined under a microscope at $100 \times$ magnification without a

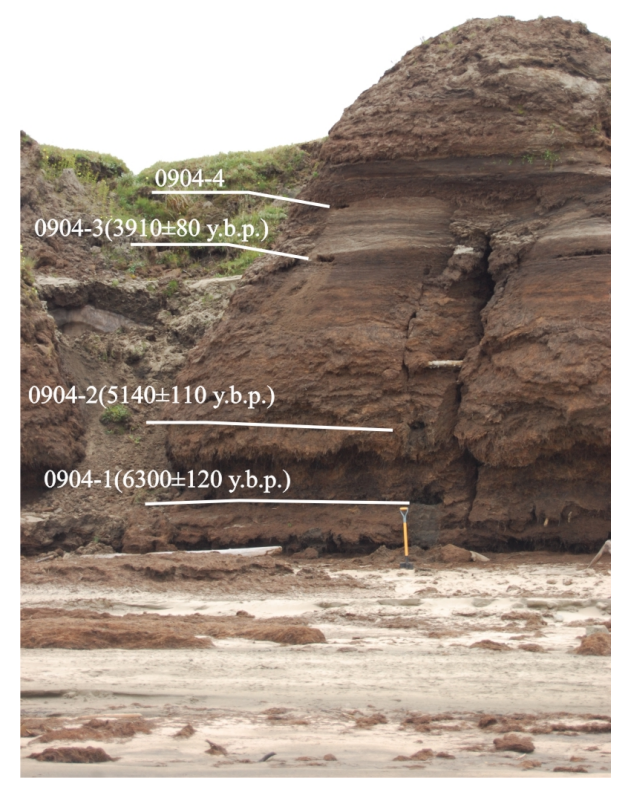

Figure 1. Typical outcrop of the layered sediments with radiocarbon dates and sample numbers. Bulkurskaya channel.

cover glass. When the plant species was difficult to identify, stronger magnification (up to $450 \times$ ) was used to view individual parts of plant remains, and in this case the sample was covered with a cover glass. The species of all plant samples were determined by using special atlases (Katz et al., 1977; Dombrovskaya et al., 1959). The percentage of each species was visually estimated in each sample and is expressed as a percentage rounded to the nearest $5 \%$. Plant residues encountered in quantities of less than $5 \%$ were marked as being single (sol.). Determination of plant macroresidues was carried out in the Department of Biogeography at St. Petersburg State University.

\section{Results}

\subsection{Organomineral delta deposits}

Our study of geological and geomorphological Lena Delta structure showed that the first terrace, which is up to $15 \mathrm{~m}$ above sea level, is composed partly of sands, but mostly of organomineral sediments. The latter are called layered sediments, since this term most precisely reflects the essence of the structure and the composition of these sediments (Fig. 1). These layered plant masses, enriched in sand and silt to varying degrees, are made up of undecomposed green mosses, detritus of sedges and other plants, and woody remains. Horizontal and wavy bedding of sediments indicates that the plant remains were deposited in a shallow basin. These sediments 
were annually frozen, as indicated by the extensive development of syngenetic massive ice wedges. In general these Holocene sediments are very similar to ice complex (IC) deposits, although IC deposits formed at a different time, at the close of the late Pleistocene, and under much drier and colder formation conditions. In both cases the mechanism of sediment formation was probably very similar and depended, to a major extent, on sea-level fluctuations.

The botanical composition of the peat that makes up the islands is of great importance for understanding the origin of the sediment deposits. On the western extremity of SoboSise Island on the Bootulu-Sise channel side, Gusev (1953) described the second (as he presumed) $8 \mathrm{~m}$ high terrace. The lower peaty part of this terrace is composed of $50 \%$ Carex caespitosa and Carex limosa, $35 \%$ Calliergon cordifolium, C. sp., Drepanocladus sp., and Poludella squarrosa, and $15 \%$ undefined herbal remains. The peat is $15 \%$ decomposed. The middle part of this terrace consists of $30 \%$ sedges; Calliergon cordifolium, C.cuspidatum, Cirriphylum sp., Drepanocladus exanulatus, D.fluitans, and D.venicosus make up the remaining $70 \%$. The peat is $5 \%$ decomposed.

In the upper part of this terrace, new species Drepanocladus sedtheri and Mnium sp. are found, and the peat is $5 \%$ decomposed. At $1 \mathrm{~km}$ downstream from Bulunkan Bay, along the Bykovskaya channel, the base of the $6 \mathrm{~m}$ high section is composed of strongly arenaceous peat, $70 \%$ of which is made up of Calliergon cordifolium, C.giganteum, Drepanocladus exannulatus, D. Sendtheri, and D. venicasus, while $15 \%$ is Carex sp. and $15 \%$ is unidentifiable remains. Single tree trunks up to $8 \mathrm{~cm}$ in diametre] are found here. In the middle part of this terrace the peat is denser and the layering is less pronounced. Sixty percent of this section is composed of Carex caespitosa, C. limosa, and C. sp., and $20 \%$ of Calliergon cordifolium, $C$. giganteum, and Scorpidium scorpioides. The remaining $20 \%$ is made up of Drepanocladus exomulatus, $D$. sencther, and D. venicosus. The upper $2 \mathrm{~m}$ of the section are represented by horizontally layered fine-grained quartz sands with abundant interbedded peat and peat detritus.

As can be seen from the vegetation descriptions (Gusev, 1953), peat-forming plants are represented in the delta by green mosses and sedges. The peat deposits are as much as $15 \%$ decomposed; the amount of decomposition is sometimes less in the lower part of the peat bogs than in the upper part.

Our observations indicate that section 0904 (Fig. 1) on the left slope of the Bulkur channel $\left(72^{\circ} 09^{\prime} 02.8^{\prime \prime} \mathrm{N}\right.$, $126^{\circ} 15^{\prime} 57.8^{\prime \prime} \mathrm{E}$ ) is of particular interest. The first terrace, up to $13.5 \mathrm{~m}$ above the low-water mark in the Bulkur channel, is composed of organomineral sediments which exist as isolated silt pinnacle outliers that are separated from each other by valleys which formed as ice veins melted. The width of the silt pinnacle outliers approximately corresponds to the size of the polygons on the terrace surface. In one of these silt pinnacle outliers, the following units are exposed in ascending order:

- towpath (0-3.5 $\mathrm{m}$ above water edge), up to $40 \mathrm{~m}$ wide, composed of sand with sunken wood;

- plant remains in a well-developed, $4.7 \mathrm{~m}$ thick horizontal layer (sample 0904-1 taken at a height of $3.5 \mathrm{~m}$, sample 0904-2 at a height of $4.7 \mathrm{~m}$, and sample 0904-3 at a height of $8.2 \mathrm{~m}$ );

- $0.8 \mathrm{~m}$ thick sand with interbedded plant remains;

- layered plant sediments with visible thickness of $1 \mathrm{~m}$ (sample 0904-4 taken from the height of $9 \mathrm{~m}$ above water edge, at the base of the layer);

- layered plant sediments in a 3-3.5 m thick sliding block.

As is seen from Fig. 1, the organic mass in the lower half of the section (below the sandy layer) formed in the time interval between 6300 and 3900 BP. There may have been a break in sedimentation between the two lower dated layers of sediments. In the time interval between 5100 and 3900 BP, $3.5 \mathrm{~m}$ of plant remains accumulated at an average rate of $3 \mathrm{~mm} \mathrm{yr}^{-1}$ or $30 \mathrm{~cm} 100 \mathrm{yr}^{-1}$. Above this layer, sands and layered sediments were again deposited.

The results of pollen analysis from sediments of section 0904 are shown in the diagram (Fig. 2) The spore-pollen spectra of the three lower samples (0904-1, 0904-2, 0904-3) are uniform. Sediments are dominated by pollen of arboraceous and shrub vegetation (60-70\%), which does not grow in this location today. Vegetation is mainly represented by three taxa; Pinus s/g Haploxilon, Betula sp., and Alnus fruticosa account for 20 to $30 \%$. Pollen of Picea (8\%), Larix (3$5 \%$ ), and Salix (2-5\%) are also present. Herbaceous vegetation is represented by pollen of the family Cyperaceae (20$27 \%$ ) and motley grass-herb groups including, e.g. Poaceae, Brassicaceae, Artemisia, Asteraceae, Rosaceae. Spores are predominantly from sphagnum mosses, ferns, different $L y$ copodium species, and Selaginella sibirica. All samples contain sporadic pollen grains and spores of pre-Quaternary conifers. Pollen and spores in all samples are well preserved.

The spore-pollen spectrum of the upper sample (0904-4, from a height of $9 \mathrm{~m}$ above water edge) differs from those described above by the predominance of grass pollen representing the families Poaceae (38\%) and Cyperaceae (20\%), and miscellaneous herbs. There is also a high content of larch pollen $(15 \%)$, and sporadic forms of softwood stomata are recorded that could not be assigned to genera due to their poor preservation.

Among plant macroremains in the lower part of the section (sample 0904-1), sedges (30\%), cotton grass (5\%), and equisetum (5\%) were found. Mosses are represented by Drepanocladus (25\%), Tomethypnym (25\%), and Calliergon (5\%). There are single occurrences of Comarum palustre, Bryum, and Aulacomnium. 


\section{4 outcrop (Bulkur channel)}

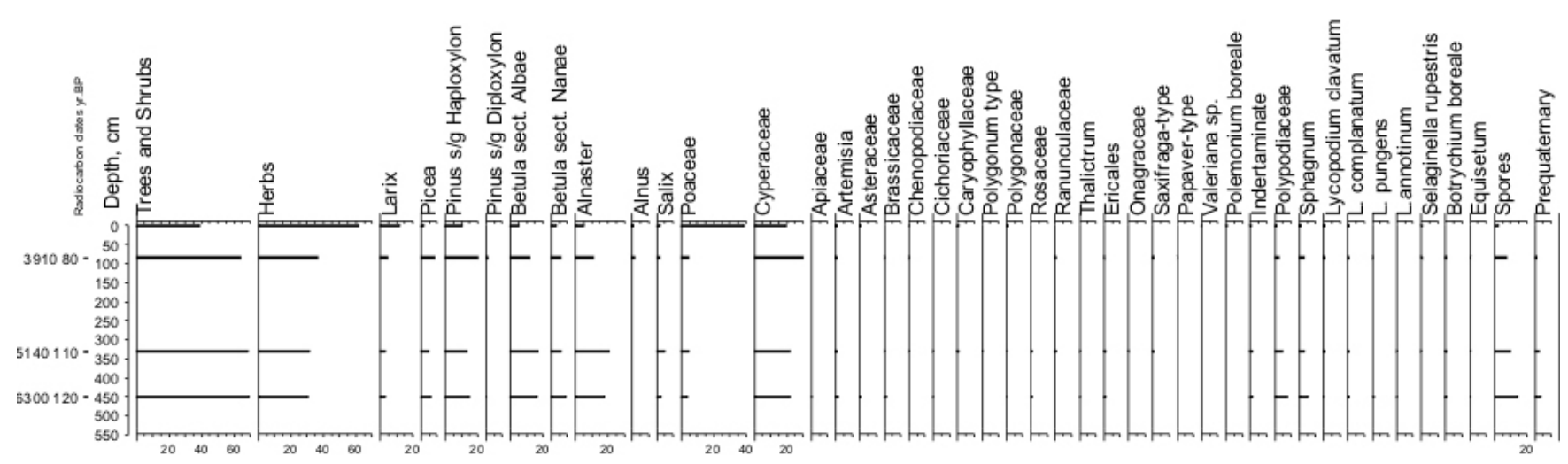

Figure 2. Spore-pollen diagram at section 0904. Bulkurskaya channel.

In sample 0904-2 the sedge species composition changes slightly. Carex cespitosa virtually disappears, but Carex rariflora appears $(10 \%)$. Carex aguatilis accounts for $10 \%$. Individual Equisetum occurs, and grasses appear (10\%). In addition, there is an increasing diversity of mosses, including Calliergon gigantenum (20\%), Drepanocladus (20\%), Calliergon cordifolium (15\%), and Bryum (5\%).

In sample 0904-3, herbaceous plants are again dominated by sedges of different species which in total account for $30 \%$. Equisetum is present in small amounts and accounts for $5 \%$. The remaining $65 \%$ of remains are composed of mosses dominated by Calliergon cordifolium (15\%), Drepanocladus (15\%), and Tomethypnym (10\%).

Sample 0904-4 is notable for a lower share of sedges $(25 \%)$, and a rather high content of grasses $(25 \%)$ and Drepanocladus $(30 \%)$. Among mosses, Calliergon cordifolium (15\%) and Campyllum (5\%) are also recorded.

All samples are very rich in organic material that has not decomposed very much (the highest amount of decomposition, $30 \%$, found in the lowest sample) and is very well preserved. All the species encountered currently grow in tundra.

Results of analyses show that the vegetation composition indicated by spore-pollen spectra differs significantly from that indicated by the plant macroremains. This difference is particularly pronounced in the mosses. In layered sediments Sphagnum and lycopod spores are present, and layered sediments are mainly composed of green mosses. The pollen and plant remains of the herbaceous vegetation are more or less similar and sedge pollen and macroremains prevail. In the upper sample, changes in the composition of herbaceous plant pollen correspond to changes in the composition of herb remains. Both macroremains and spore-pollen analyses showed an increasing presence of grasses and a decreasing presence of sedges. Macroremains contain virtually no arboraceous species, which probably indicates that the de- scribed area remained in the tundra zone during the time interval from 6300 to $3900 \mathrm{BP}$.

Our own and previous studies suggest that the organic part of the layered sediments is virtually undecomposed. The maximum $15 \%$ of peat decomposition degree determined by Gusev (1953) is accounted for by indefinite plant remains, i.e. by plant detritus, which is not a product of decomposition, but was transported to this location by water, as were the green mosses and herbaceous plants. As is evident from the descriptions, there are abundant remains of both sedge roots and leaves in layered sediments. Peat is generally not characterised by the presence of sedge leaves, since they decompose quickly (Denisenkov, 2000).

The mineral proportion of the layered sediments differs significantly from section to section. In general, the amount of sand is much greater in the southern part of the delta than in the northern parts. Tit-Ary is the first island of the delta, and sand makes up 30-40\% of the volume weight of these sections. In other sections (closest to the Laptev Sea) sandy material accounts for less than $10 \%$ in layered sediment sections.

Layered sediments accumulate at a very high rate, ranging from 0.2 to $1.6 \mathrm{~m}$ per hundred years. In the Samoylov Island borehole, the lower metre of sediments accumulated during several dozens of years only.

In layered sediment sections of the first terrace up to $8 \mathrm{~m}$ thick, the upper and lower parts exhibit a nearly identical degree of moss decomposition.

Wood remains protruding from exposures are, as a rule, much younger than the accumulations of mosses and plant detritus, as was shown by radiocarbon dating. The location of the dated first terrace organomineral sediment sections is shown in Fig. 3; dates are given in Table 1. 


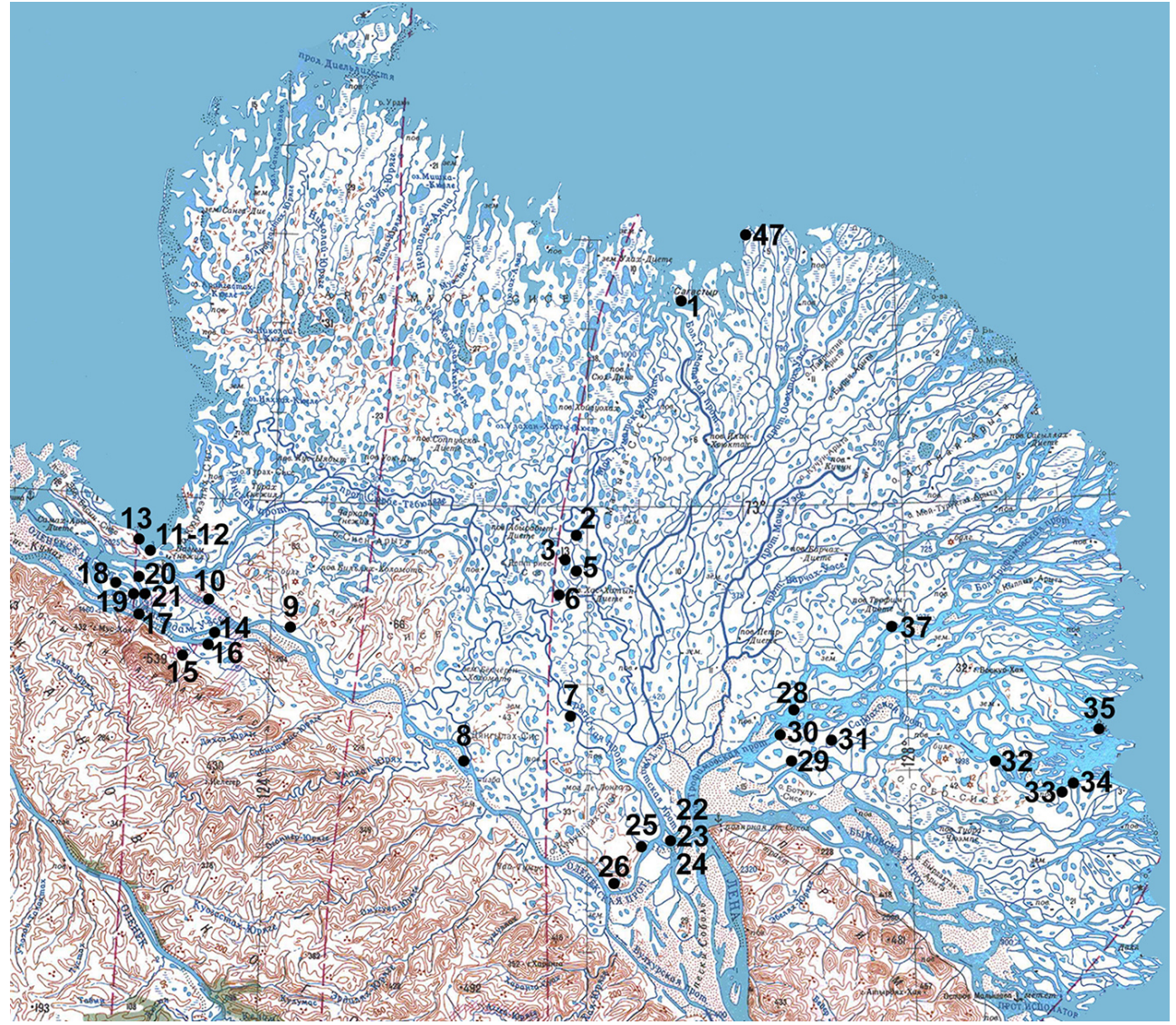

Figure 3. Map of the studied sites in the Lena River delta.

\subsection{Geomorphological delta structure}

The geological and geomorphological structures of delta islands obviously point to the fact that the first terrace formed during several phases of alternating accumulation and erosion of sediments. Island outlines clearly illustrate different ages of sediments on the same first terrace surface. Figure 4 presents an aerial picture of Samoylov Island. Its eastern part is polygonal tundra made up almost entirely by organic layered sediments up to several metres thick. A developed system of polygons and thermokarst lakes points to the comparatively long existence of the first terrace surface. The western part of the island is composed of sands adjoining the eastern part of the island. Surface sands on the western part of the first terrace exhibit only rudimentary polygonal forms and are covered with sparser vegetation than is the eastern part of the island. The first terrace surface is younger than a similar surface on the eastern part of the island. The western slope of the island is most affected by flood water, which leaves an annual deposit of sandy material atop it. A large amount of driftwood accumulates here, i.e. tree trunks and their fragments brought by the river and deposited as the river water recedes. Boreholes drilled in the sands of the western part of the island showed that 300-500 year old sands were de- posited on 2600 year old eroded layered sediments near the modern water edge (Table 1, no. 23).

Samoylov Island was formed by the accumulation of layered sediments at 3500-2500 BP under basin conditions as indicated by horizontal and wavy sediment layers. These sediments were subsequently eroded, and at $300-500 \mathrm{BP}$ the erosional outlier was joined from the west by river floodplain deposits composed of sands and plant detritus. Such major differences in the accumulation mode of organic vs. sandy deposits can only be associated with opposite phases of delta evolution: a period of still water and accumulation of light organic deposits under estuarine conditions at 3500-2500 BP, followed by a period of riverbed downcutting by erosion.

Similar ratios of differently aged island sediments composed of organomineral layered sediments and sandy sediments were recorded in the course of geomorphological surveying in many Lena River delta areas. Compilation of the geomorphological map of the delta (Makarov, 2009) revealed the unevenly aged structure of the individual alluvial fans that form the delta (Fig. 5). As a result of deciphering photos and comparing results with the relief structure description compiled in the course of geological and geomorphological investigations and the radiocarbon dates of terrace sediments, it was possible to distinguish alluvial fans of uniform proper- 


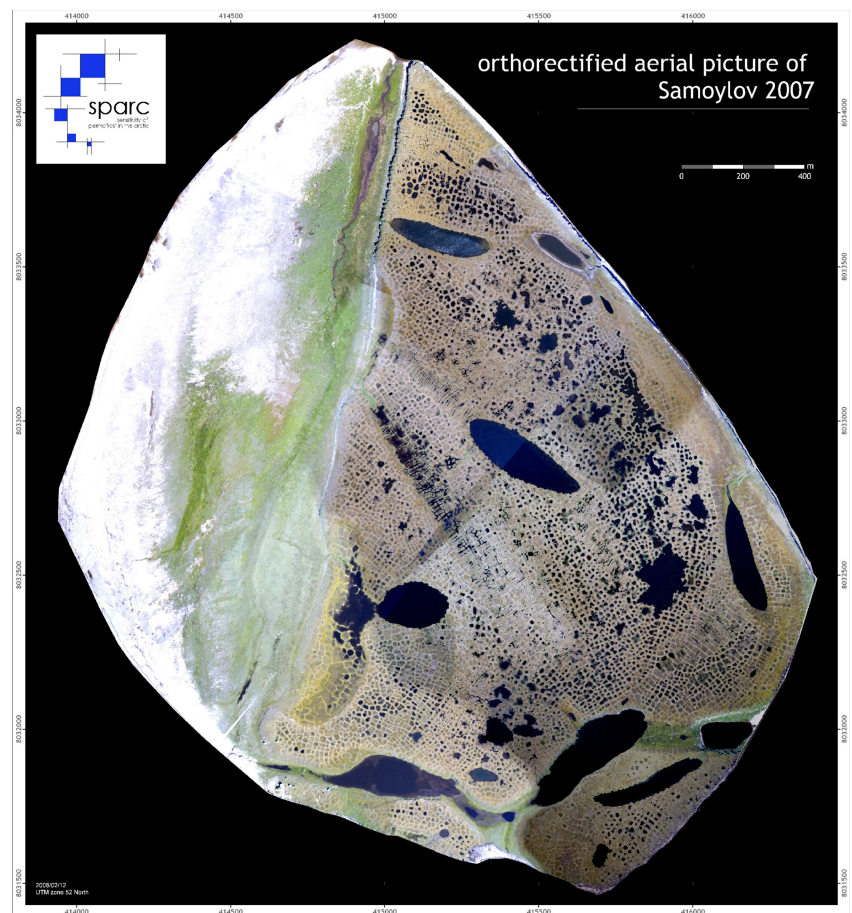

Figure 4. Aerial picture of Samoylov Island.

ties and age which together form the surface of the first Lena River delta terrace.

The most ancient parts of the first terrace are the islands lying at the boundary of the Arynskaya and Tumatskaya channels. The age of the terrace here is $8570 \mathrm{BP}$ (lab. no. LU4191 , no. 2, Table 1), and the height of the islands reaches $8 \mathrm{~m}$.

Another major constituent of the first terrace is a massif of islands in the Lena River delta Olenekskaya and Arynskaya channels. These islands began to form about seven thousand years ago (6890 \pm 170 , LU-4409; $6520 \pm 130$, LU-4407). The islands are $10-12 \mathrm{~m}$ high. The Tumatskaya alluvial fan is 2500-3000 years old ( $2280 \pm 8$, LU-5611; $3170 \pm 60$, LU5612). Islands in this part of the delta are relatively low-lying at $7-8 \mathrm{~m}$, and only $1-1.5 \mathrm{~m}$ high on the coastal area. The Sardakh or Sardakh-Trofimovsky fan formed starting around $4000 \mathrm{BP}$; islands on this fan reach $10-12 \mathrm{~m}$ in height.

The youngest formations in the delta are the Bykovskaya channel islands which are $10 \mathrm{~m}$ high, and are moving forward to the Laptev Sea through an extensive alluvial fan. These islands are not more than 2500 years old $(1400 \pm 100$ and $2530 \pm 200$, MSU-773 and MSU-861, respectively; Korotaev, 1984). The surface of the entire terrace slopes from the delta head $(10-12 \mathrm{~m})$ to the sea edge $(0.5 \mathrm{~m})$. Thus, the first terrace alluvial fans accumulated first in the west, and then the formation moved to the east. The oldest delta islands lie in its western part; the young ones, in the eastern part. This peculiar delta formation can be accounted for by the tectonic movements which are clearly recorded in sections of the some islands (Bolshiyanov et al., 2013).

\section{Discussion}

Islands composed of deposits of different ages and types are common in the Lena River delta. Their geological structure points to an abrupt change in the sedimentation environment, both laterally and vertically, and with time. This process of island formation contradicts the accepted doctrine of sedimentation in deltas.

It is presumed that delta islands accrete upwards as a result of annually precipitated silt deposits that are left behind as high water recedes, as occurs in river valleys. The following is one of the traditional notions of the delta origins:

Modern delta islands form due to a gradual rising of sandy-silty bars at the sea edge or during breakage of channel bends. Shoals are gradually transformed into above-water 'sands', which are covered with bush-like grass vegetation strengthening their surface against weathering and promoting their growth in height due to detaining drift during high water. With further rising, the vegetation becomes thicker, and the islands become dry sandy tundra. With age, ever thicker moss-turf and peat surface layers accrete on the islands. A moss cushion forms, bogging-up of soil starts, and a cover of hydrophilic plants appears. Thickness of the active thawing layer decreases, and typical tundra of the permafrost area appears. Frost cracks form (Samoilov, 1952).

A key issue of delta formation is the origin of organomineral masses, the layered sediments that make up most of delta islands. Virtually all researchers regard these sediments as peat.

Over the vast plain land areas with severe continental climate favourable conditions set in for the development of bog-tundra vegetation. The lower peat bogs formed as a result of overgrowth of water bodies in near-Arctic regions, whereas the upper peat bogs (Mammoth Horizon) are characteristic of wet marshes and overgrowing water bodies of tundra type. Peat accumulation on all three terraces of the delta inevitably proceeded following the type of lowland hypnum or sedge hypnum bogs (Gusev, 1959).

The three terraces proposed by Gusev (1959) are, in fact, a single terrace, the first delta terrace which is composed of organomineral sediments.

In general, the described deposits are quite dissimilar from peat deposits in composition and texture. 
Table 1. Radiocarbon and Calibration was made using OxCal programme v.4.2 (Ramsey et al., 2010) and calibration curve IntCal13 (Reimer et al., 2013).

\begin{tabular}{|c|c|c|c|c|c|c|c|}
\hline No. & $\begin{array}{l}\text { Location, channel, } \\
\text { island }\end{array}$ & Coordinates & $\begin{array}{l}\text { Geomorphic } \\
\text { position }\end{array}$ & $\begin{array}{l}\text { Height } \\
\text { (m above } \\
\text { water level) }\end{array}$ & $\begin{array}{l}\text { Lab no., } \\
\text { reference }\end{array}$ & C14 age & $\begin{array}{l}\text { C14 age } \\
\text { calibrated }\end{array}$ \\
\hline 1 & $\begin{array}{l}\text { Bol'shaya Tumatskaya } \\
\text { channel, } \\
\text { Sagastyr Island }\end{array}$ & $\begin{array}{l}73^{\circ} 22^{\prime} 17^{\prime \prime} \mathrm{N} \\
125^{\circ} 50^{\prime} 22^{\prime \prime} \mathrm{E}\end{array}$ & $\begin{array}{l}\text { Alluvial- } \\
\text { estuarine } \\
\text { terrace } 3-4 \mathrm{~m} \\
\text { height }\end{array}$ & 3.1 & LU-4201 & $1400 \pm 80$ & $1319 \pm 80$ \\
\hline 2 & $\begin{array}{l}\text { Malaya Tumatskaya } \\
\text { channel, } \\
\text { Chenchike-Sise Island }\end{array}$ & $\begin{array}{l}72^{\circ} 57^{\prime} 09^{\prime \prime} \mathrm{N} \\
125^{\circ} 55^{\prime} 06^{\prime \prime} \mathrm{E}\end{array}$ & $\begin{array}{l}\text { Alluvial- } \\
\text { estuarine } \\
\text { terrace } 4-7 \mathrm{~m}\end{array}$ & 2.5 & LU-4191 & $8570 \pm 160$ & $9625 \pm 223$ \\
\hline 3 & $\begin{array}{l}\text { Malaya Tumatskaya } \\
\text { channel, } \\
\text { Dgipiries Island }\end{array}$ & $\begin{array}{l}72^{\circ} 54^{\prime} 43^{\prime \prime} \mathrm{N} \\
125^{\circ} 52^{\prime} 30^{\prime \prime} \mathrm{E}\end{array}$ & $\begin{array}{l}\text { Alluvial- } \\
\text { estuarine } \\
\text { terrace } \\
10-11 \mathrm{~m} \text { on the } \\
\text { Pleistocene } \\
\text { basis }\end{array}$ & 9.0 & LU-4412 & $6460 \pm 100$ & $7370 \pm 92$ \\
\hline 4 & $\begin{array}{l}\text { Malaya Tumatskaya } \\
\text { channel, } \\
\text { Chenchike-Sise Island }\end{array}$ & $\begin{array}{l}72^{\circ} 51^{\prime} 58^{\prime \prime} \mathrm{N} \\
125^{\circ} 55^{\prime} 08^{\prime \prime} \mathrm{E}\end{array}$ & $\begin{array}{l}\text { Alluvial- } \\
\text { estuarine } \\
\text { terrace } 9-10 \mathrm{~m}\end{array}$ & 7.8 & LU-4197 & $1880 \pm 120$ & $1819 \pm 146$ \\
\hline 5 & $\begin{array}{l}\text { Malaya Tumatskaya } \\
\text { channel, } \\
\text { Dgipiries-Sise Island, } \\
\text { N-E coast of the Lake } \\
\text { Yugus-Dgie-Kyuele }\end{array}$ & $\begin{array}{l}72^{\circ} 51^{\prime} 14^{\prime \prime} \mathrm{N} \\
125^{\circ} 50^{\prime} 22^{\prime \prime} \mathrm{E}\end{array}$ & $\begin{array}{l}\text { Alluvial- } \\
\text { estuarine } \\
\text { terrace } \\
10-11 \mathrm{~m} \text { on the } \\
\text { Pleistocene } \\
\text { basis }\end{array}$ & 7.5 & LU-4198 & $6430 \pm 120$ & $7337 \pm 117$ \\
\hline 6 & $\begin{array}{l}\text { Malaya Tumatskaya } \\
\text { channel, } \\
\text { Dgipiries-Tubelege, } \\
\text { Tyuba-Aryta Island }\end{array}$ & $\begin{array}{l}72^{\circ} 49^{\prime} 45^{\prime \prime} \mathrm{N} \\
125^{\circ} 49^{\prime} 40^{\prime \prime} \mathrm{E}\end{array}$ & $\begin{array}{l}\text { Alluvial- } \\
\text { estuarine } \\
\text { terrace } 8.5-9 \mathrm{~m}\end{array}$ & $\begin{array}{l}5.8 \\
7.0\end{array}$ & $\begin{array}{l}\text { LU-4193 } \\
\text { LU-4199 }\end{array}$ & $\begin{array}{l}2690 \pm 100 \\
1320 \pm 80\end{array}$ & $\begin{array}{l}2812 \pm 129 \\
1226 \pm 81\end{array}$ \\
\hline 7 & $\begin{array}{l}\text { Arynskaya channel, } \\
\text { Buor-Syr-Aryta Island }\end{array}$ & $\begin{array}{l}72^{\circ} 36^{\prime} 50^{\prime \prime} \mathrm{N} \\
125^{\circ} 53^{\prime} 30^{\prime \prime} \mathrm{E}\end{array}$ & $\begin{array}{l}\text { Alluvial- } \\
\text { estuarine } \\
\text { terrace } \\
8.5 \mathrm{~m}\end{array}$ & 5.2 & LU-4413 & $3930 \pm 90$ & $4368 \pm 141$ \\
\hline 8 & $\begin{array}{l}\text { Olenekskaya channel, } \\
\text { Tyuyarenkey-Tubelege } \\
\text { (Gusinka) } \\
\text { Dzhangilakh-Sise } \\
\text { Island }\end{array}$ & $\begin{array}{l}72^{\circ} 29^{\prime} 33^{\prime \prime} \mathrm{N} \\
125^{\circ} 18^{\prime} 45^{\prime \prime} \mathrm{E}\end{array}$ & $\begin{array}{l}\text { Alluvial- } \\
\text { estuarine } \\
\text { terrace } \\
9-13 \mathrm{~m}\end{array}$ & $\begin{array}{l}7.6 \\
10.7\end{array}$ & $\begin{array}{l}\text { LU-4409 } \\
\text { LU-4407 }\end{array}$ & $\begin{array}{l}6890 \pm 170 \\
6520 \pm 130\end{array}$ & $\begin{array}{l}7752 \pm 140 \\
7418 \pm 116\end{array}$ \\
\hline 9 & $\begin{array}{l}\text { Olenekskaya channel, } \\
\text { Khardang Island }\end{array}$ & $\begin{array}{l}72^{\circ} 45^{\prime} 26^{\prime \prime} \mathrm{N} \\
124^{\circ} 05^{\prime} 26^{\prime \prime} \mathrm{E}\end{array}$ & $\begin{array}{l}\text { Alluvial- } \\
\text { estuarine } \\
\text { terrace } 5-7 \mathrm{~m}\end{array}$ & 2.0 & LU-4411 & $5100 \pm 140$ & $5862 \pm 162$ \\
\hline 10 & $\begin{array}{l}\text { Olenekskaya } \\
\text { channel, } \\
\text { Khardang Island }\end{array}$ & $\begin{array}{l}72^{\circ} 48^{\prime} 06^{\prime \prime} \mathrm{N} \\
123^{\circ} 37^{\prime} 28^{\prime \prime} \mathrm{E}\end{array}$ & $\begin{array}{l}\text { Alluvial- } \\
\text { estuarine } \\
\text { terrace } 4-5 \mathrm{~m}\end{array}$ & 2.0 & LU-4414 & $2850 \pm 200$ & $3016 \pm 243$ \\
\hline 11 & $\begin{array}{l}\text { Kuba Bay } \\
\text { Ebe-Bsyn-Sise Island }\end{array}$ & $\begin{array}{l}72^{\circ} 55^{\prime} 06^{\prime \prime} \mathrm{N} \\
123^{\circ} 57^{\prime} 50^{\prime \prime} \mathrm{E}\end{array}$ & $\begin{array}{l}\text { Marine terrace } \\
1.2-4 \mathrm{~m}\end{array}$ & 2.5 & LU-4548 & $1170 \pm 50$ & $1096 \pm 69$ \\
\hline 12 & $\begin{array}{l}\text { Kuba Bay } \\
\text { Ebe-Bsyn-Sise Island }\end{array}$ & $\begin{array}{l}72^{\circ} 53^{\prime} 31^{\prime \prime} \mathrm{N} \\
123^{\circ} 11^{\prime} 20^{\prime \prime} \mathrm{E}\end{array}$ & $\begin{array}{l}\text { Marine terrace } \\
3.5 \mathrm{~m} \text { setup } \\
\text { wood }\end{array}$ & $\begin{array}{l}3.2 \\
4.0\end{array}$ & $\begin{array}{l}\text { LU-4545 } \\
\text { LU-4547 }\end{array}$ & $\begin{array}{l}750 \pm 40 \\
180 \pm 50\end{array}$ & $\begin{array}{l}691 \pm 29 \\
161 \pm 92\end{array}$ \\
\hline 13 & $\begin{array}{l}\text { Kuba Bay } \\
\text { Ebe-Bsyn-Sise Island }\end{array}$ & $\begin{array}{l}72^{\circ} 53.796^{\prime} \mathrm{N} \\
123^{\circ} 10.186^{\prime} \mathrm{E}\end{array}$ & $\begin{array}{l}\text { Marine terrace } \\
5-8.5 \mathrm{~m} \\
\text { Marine terrace } \\
2.5-3 \mathrm{~m}\end{array}$ & $\begin{array}{l}3.5 \\
2.3\end{array}$ & $\begin{array}{l}\text { LU-4551 } \\
\text { LU-4544 }\end{array}$ & $\begin{array}{l}3620 \pm 60 \\
1220 \pm 40\end{array}$ & $\begin{array}{l}3940 \pm 88 \\
1151 \pm 61\end{array}$ \\
\hline 14 & $\begin{array}{l}\text { Angardam channel, } \\
\text { Kharayalakh-Ary } \\
\text { Island }\end{array}$ & $\begin{array}{l}72^{\circ} 44^{\prime} 50^{\prime \prime} \mathrm{N} \\
123^{\circ} 38^{\prime} 00^{\prime \prime} \mathrm{E}\end{array}$ & $\begin{array}{l}\text { Alluvial- } \\
\text { estuarine } \\
\text { terrace } 5.5 \mathrm{~m}\end{array}$ & 2.8 & LU-4564 & $410 \pm 60$ & $434 \pm 67$ \\
\hline
\end{tabular}




\begin{tabular}{|c|c|c|c|c|c|c|c|}
\hline No. & $\begin{array}{l}\text { Location, channel, } \\
\text { island }\end{array}$ & Coordinates & $\begin{array}{l}\text { Geomorphic } \\
\text { position }\end{array}$ & $\begin{array}{l}\text { Height } \\
\text { (m above } \\
\text { water level) }\end{array}$ & $\begin{array}{l}\text { Lab no., } \\
\text { reference }\end{array}$ & C14 age & $\begin{array}{l}\text { C14 age } \\
\text { calibrated }\end{array}$ \\
\hline 15 & $\begin{array}{l}\text { Angardam channel, } \\
\text { Dzhakhse- Tubelege } \\
\text { Angardam Ridge } \\
\text { bottom }\end{array}$ & $\begin{array}{l}72^{\circ} 42.813^{\prime} \mathrm{N} \\
123^{\circ} 29.970^{\prime} \mathrm{E}\end{array}$ & $\begin{array}{l}\text { Alluvial- } \\
\text { estuarine } \\
\text { terrace } 5-5.5 \mathrm{~m}\end{array}$ & 1.7 & LU-4569 & $2390 \pm 50$ & $2472 \pm 106$ \\
\hline 16 & $\begin{array}{l}\text { Angardam channel, } \\
\text { Ulakhan-Ary Island }\end{array}$ & $\begin{array}{l}72^{\circ} 43.777^{\prime} \mathrm{N} \\
123^{\circ} 29.442^{\prime} \mathrm{E}\end{array}$ & $\begin{array}{l}\text { Alluvial- } \\
\text { estuarine } \\
\text { terrace } 8-9 \mathrm{~m}\end{array}$ & $\begin{array}{l}0.5 \\
1\end{array}$ & $\begin{array}{l}\text { LU-4541 } \\
\text { LU-4542 }\end{array}$ & $\begin{array}{l}2600 \pm 50 \\
790 \pm 40\end{array}$ & $\begin{array}{l}2700 \pm 86 \\
716 \pm 31\end{array}$ \\
\hline 17 & $\begin{array}{l}\text { Angardam channel, } \\
\text { Olenek-Kumaga sands }\end{array}$ & $\begin{array}{l}72^{\circ} 47.353^{\prime} \mathrm{N} \\
123^{\circ} 07.511^{\prime} \mathrm{E}\end{array}$ & $\begin{array}{l}\text { Sand island in a } \\
\text { channel, } 1.7 \mathrm{~m}\end{array}$ & -0.35 & LU-4563 & $3400 \pm 60$ & $3657 \pm 84$ \\
\hline 18 & $\begin{array}{l}\text { Angardam channel, } \\
\text { Belkey Island }\end{array}$ & $\begin{array}{l}72^{\circ} 49.531^{\prime} \mathrm{N} \\
123^{\circ} 05.264^{\prime} \mathrm{E}\end{array}$ & $\begin{array}{l}\text { Bulguniagkh } \\
12 \mathrm{~m} \text { on the } \\
\text { surface of } 5 \mathrm{~m} \\
\text { flood-plain }\end{array}$ & 5.2 & LU-4561 & $6020 \pm 110$ & $6887 \pm 145$ \\
\hline 19 & $\begin{array}{l}\text { Angardam channel- } \\
\text { Olenekskaya channel, } \\
\text { Belkey Island }\end{array}$ & $\begin{array}{l}72^{\circ} 49.063^{\prime} \mathrm{N} \\
123^{\circ} 09.557^{\prime} \mathrm{E}\end{array}$ & $\begin{array}{l}\text { Driftwood, } \\
4 \mathrm{~m} \text { bottom of } \\
\text { termokarst lake }\end{array}$ & 4 & LU-4546 & $220 \pm 40$ & $199 \pm 104$ \\
\hline 20 & $\begin{array}{l}\text { Belkey-Aryn-Uesya } \\
\text { channel, } \\
\text { Soduom-Aryta Island }\end{array}$ & $\begin{array}{l}72^{\circ} 50.254^{\prime} \mathrm{N} \\
123^{\circ} 11.596^{\prime} \mathrm{E}\end{array}$ & $\begin{array}{l}\text { Alluvial- } \\
\text { estuarine } \\
\text { terrace } 1.5-2 \mathrm{~m}\end{array}$ & 0.9 & LU-4572 & $1770 \pm 50$ & $1690 \pm 68$ \\
\hline 21 & $\begin{array}{l}\text { Samoim-Uesya } \\
\text { channel, } \\
\text { Tyalyr-Mengenyakh- } \\
\text { Ary Island }\end{array}$ & $\begin{array}{l}72^{\circ} 45.481^{\prime} \mathrm{N} \\
123^{\circ} 10.463^{\prime} \mathrm{E}\end{array}$ & $\begin{array}{l}\text { Alluvial- } \\
\text { estuarine } \\
\text { terrace } 7 \mathrm{~m}\end{array}$ & 4 & LU-4568 & $1710 \pm 60$ & $1627 \pm 75$ \\
\hline 22 & $\begin{array}{l}\text { Bol'shaya Tumatskaya } \\
\text { channel, } \\
\text { Samoylovsky channel }\end{array}$ & $\begin{array}{l}72^{\circ} 22.103^{\prime} \mathrm{N} \\
126^{\circ} 29.581^{\prime} \mathrm{E}\end{array}$ & $\begin{array}{l}\text { Alluvial- } \\
\text { estuarine } \\
\text { terrace } \\
8.5-10 \mathrm{~m}\end{array}$ & 2.5 & LU-4577 & $3220 \pm 70$ & $3451 \pm 81$ \\
\hline 23 & $\begin{array}{l}\text { Bol'shaya Tumatskaya } \\
\text { channel, } \\
\text { Samoylovsky channel } \\
\text { (borehole) }\end{array}$ & & $\begin{array}{l}\text { Alluvial- } \\
\text { estuarine } \\
\text { terrace } \\
8.5-10 \mathrm{~m}\end{array}$ & $\begin{array}{l}7.5 \\
6.6 \\
6.2 \\
1.3 \\
1.2 \\
0.4\end{array}$ & $\begin{array}{l}\text { Schwamborn et } \\
\text { al. }(2000) \\
\text { KIA-8169 } \\
\text { KIA- } 8170 \\
\text { KIA- } 8171 \\
\text { KIA-8172 } \\
\text { KIA-8173 } \\
\text { KIA- } 8174\end{array}$ & $\begin{array}{l}435 \pm 30 \\
230 \pm 25 \\
500 \pm 25 \\
2605 \pm 30 \\
2530 \pm 30 \\
2635 \pm 35\end{array}$ & $\begin{array}{l}492 \pm 35 \\
219 \pm 89 \\
526 \pm 14 \\
2743 \pm 25 \\
2622 \pm 81 \\
2763 \pm 25\end{array}$ \\
\hline 24 & $\begin{array}{l}\text { Bol'shaya Tumatskaya } \\
\text { channel, } \\
\text { Samoylovsky channel }\end{array}$ & & $\begin{array}{l}\text { Alluvial- } \\
\text { estuarine } \\
\text { terrace } \\
8.5-10 \mathrm{~m}\end{array}$ & $\begin{array}{l}6.2 \\
4.2 \\
3.6\end{array}$ & $\begin{array}{l}\text { Kuptsov and } \\
\text { Lisitsin (1996) } \\
\text { IORAN-4167 } \\
\text { IORAN-4164 } \\
\text { IORAN-4101 }\end{array}$ & $\begin{array}{l}3700 \pm 260 \\
4220 \pm 240 \\
2140 \pm 110\end{array}$ & $\begin{array}{l}4091 \pm 349 \\
4783 \pm 336 \\
2134 \pm 135\end{array}$ \\
\hline 25 & $\begin{array}{l}\text { Olenekskaya } \\
\text { channel, } \\
\text { Arga- } \\
\text { Aryta }\end{array}$ & $\begin{array}{l}72^{\circ} 21.713^{\prime} \mathrm{N} \\
126^{\circ} 19.588^{\prime} \mathrm{E}\end{array}$ & $\begin{array}{l}\text { Alluvial- } \\
\text { estuarine } \\
\text { terrace } 8-10 \mathrm{~m}\end{array}$ & $\begin{array}{l}7 \\
3.5\end{array}$ & $\begin{array}{l}\text { LU-4565 } \\
\text { LU-4609 }\end{array}$ & $\begin{array}{l}540 \pm 60 \\
3170 \pm 50\end{array}$ & $\begin{array}{l}572 \pm 47 \\
3391 \pm 61\end{array}$ \\
\hline 26 & $\begin{array}{l}\text { Olenekskaya } \\
\text { Kurungnakh Island. } \\
\text { Bulkurskaya channel } \\
\text { mouth area }\end{array}$ & & $\begin{array}{l}\text { Alluvial- } \\
\text { estuarine } \\
\text { terrace } 8-12 \mathrm{~m}\end{array}$ & & $\begin{array}{l}\text { Korotaev } \\
(1984) \\
\text { MGU-862 }\end{array}$ & $3480 \pm 500$ & $3877 \pm 651$ \\
\hline 27 & $\begin{array}{l}\text { Olenekskaya channel, } \\
\text { Gagariy Island }\end{array}$ & & & & $\begin{array}{l}\text { Korotaev } \\
(1984) \\
\text { MGU-808 }\end{array}$ & $4200 \pm 250$ & $4756 \pm 349$ \\
\hline
\end{tabular}




\begin{tabular}{|c|c|c|c|c|c|c|c|}
\hline No. & $\begin{array}{l}\text { Location, } \\
\text { channel, island }\end{array}$ & Coordinates & $\begin{array}{l}\text { Geomorphic } \\
\text { position }\end{array}$ & $\begin{array}{l}\text { Height } \\
\text { (m above } \\
\text { water level) }\end{array}$ & $\begin{array}{l}\text { Lab no., } \\
\text { reference }\end{array}$ & C14 age & $\begin{array}{l}\text { C14 age } \\
\text { calibrated }\end{array}$ \\
\hline 28 & $\begin{array}{l}\text { Malaya Trofimovskaya } \\
\text { channel, } \\
\text { Gogolevsky Island }\end{array}$ & $\begin{array}{l}72^{\circ} 36.980^{\prime} \mathrm{N} \\
127^{\circ} 15.708^{\prime} \mathrm{E}\end{array}$ & $\begin{array}{l}\text { Alluvial- } \\
\text { estuarine } \\
\text { terrace } 7 \mathrm{~m}\end{array}$ & 0.5 & LU-4911 & $3550 \pm 60$ & $3835 \pm 87$ \\
\hline 29 & $\begin{array}{l}\text { Maastakh-Uesya } \\
\text { channel, } \\
\text { Sardakh-Aryta Island. }\end{array}$ & $\begin{array}{l}72^{\circ} 31.333^{\prime} \mathrm{N} \\
127^{\circ} 05.167^{\prime} \mathrm{E}\end{array}$ & $\begin{array}{l}\text { Alluvial- } \\
\text { estuarine } \\
\text { terrace } 7 \mathrm{~m} \\
\text { Beach ridge }\end{array}$ & $\begin{array}{l}4.0 \\
9.4\end{array}$ & $\begin{array}{l}\text { LU-4914 } \\
\text { LU-4910 }\end{array}$ & $\begin{array}{l}1840 \pm 70 \\
\text { modern }\end{array}$ & $1768 \pm 84$ \\
\hline 30 & $\begin{array}{l}\text { Maastakh-Uesya } \\
\text { channel, } \\
\text { Sardakh-Aryta Island. }\end{array}$ & & $\begin{array}{l}\text { Alluvial- } \\
\text { estuarine } \\
\text { terrace } 8-9 \mathrm{~m}\end{array}$ & $\begin{array}{l}8.5 \\
8.1 \\
6.6 \\
3.9 \\
1.7 \\
0.6 \\
-0.2\end{array}$ & $\begin{array}{l}\text { Schwamborn et } \\
\text { al. }(2000) \\
\text { KIA-6759 } \\
\text { KIA-6760 } \\
\text { KIA-6761 } \\
\text { KIA-6762 } \\
\text { KIA-6763 } \\
\text { KIA-6764 } \\
\text { KIA-6765 }\end{array}$ & $\begin{array}{l}2755 \pm 25 \\
1369 \pm 20 \\
2525 \pm 30 \\
3460 \pm 30 \\
3025 \pm 35 \\
3420 \pm 35 \\
2830 \pm 35\end{array}$ & $\begin{array}{l}2841 \pm 36 \\
1293 \pm 9 \\
2616 \pm 79 \\
3736 \pm 56 \\
3229 \pm 63 \\
3677 \pm 57 \\
2936 \pm 50\end{array}$ \\
\hline 31 & $\begin{array}{l}\text { Noname channel, in } \\
\text { the line of NW from } \\
\text { the Sardakh Island, } \\
\text { Dzhielyakh-Ordono- } \\
\text { Aryta Island }\end{array}$ & $\begin{array}{l}72^{\circ} 33.184^{\prime} \mathrm{N} \\
127^{\circ} 32.845^{\prime} \mathrm{E}\end{array}$ & $\begin{array}{l}\text { Alluvial- } \\
\text { estuarine } \\
\text { terrace } 10 \mathrm{~m}\end{array}$ & 2.0 & LU-5080 & $3830 \pm 90$ & $4234 \pm 131$ \\
\hline 32 & $\begin{array}{l}\text { Sardakhskaya channel, } \\
\text { Sobo-Sise Island, } \\
\text { Boruo hole }\end{array}$ & $\begin{array}{l}72^{\circ} 27.382^{\prime} \mathrm{N} \\
128^{\circ} 56.741^{\prime} \mathrm{E}\end{array}$ & $\begin{array}{l}\text { Alluvial- } \\
\text { estuarine } \\
\text { terrace } 4 \mathrm{~m}\end{array}$ & 0.5 & LU-4916 & $5220 \pm 60$ & $6007 \pm 89$ \\
\hline 33 & $\begin{array}{l}\text { Sardakhskaya channel, } \\
\text { Sobo-Sise Island. }\end{array}$ & $\begin{array}{l}72^{\circ} 27.382^{\prime} \mathrm{N} \\
128^{\circ} 56.741^{\prime} \mathrm{E}\end{array}$ & $\begin{array}{l}\text { Alluvial- } \\
\text { estuarine } \\
\text { terrace } \\
15-16 \mathrm{~m}\end{array}$ & $\begin{array}{l}5.0 \\
13.5\end{array}$ & $\begin{array}{l}\text { LU-4913 } \\
\text { LU-4917 }\end{array}$ & $\begin{array}{l}16630 \pm 130 \\
2320 \pm 70\end{array}$ & $\begin{array}{l}20068 \pm 180 \\
2357 \pm 131\end{array}$ \\
\hline 34 & $\begin{array}{l}\text { Sardakhskaya channel, } \\
\text { Kuba-Ayanyn-Aryta Is- } \\
\text { land, NW of the Sobo- } \\
\text { Sise Island }\end{array}$ & $\begin{array}{l}72^{\circ} 27.441^{\prime} \mathrm{N} \\
128^{\circ} 57.252^{\prime} \mathrm{E}\end{array}$ & $\begin{array}{l}\text { Past delta of the } \\
\text { Bykovskaya } \\
\text { channel } \\
2-2.5 \mathrm{~m}\end{array}$ & $\begin{array}{l}0.6, \text { wood } \\
1.0 \text { detritus }\end{array}$ & $\begin{array}{l}\text { LU-5073 } \\
\text { LU-4919 }\end{array}$ & $\begin{array}{l}1140 \pm 40 \\
2920 \pm 70\end{array}$ & $\begin{array}{l}1057 \pm 61 \\
3070 \pm 101\end{array}$ \\
\hline 35 & $\begin{array}{l}\text { Toyonokh-Uesya chan- } \\
\text { nel, mouth of the } \\
\text { Trofimovskaya channel } \\
\text { area, Arangastakh } \\
\text { Island }\end{array}$ & $\begin{array}{l}72^{\circ} 33.203^{\prime} \mathrm{N} \\
129^{\circ} 12.701^{\prime} \mathrm{E}\end{array}$ & $\begin{array}{l}\text { Island on the } \\
\text { sea edge of } \\
\text { the delta } \\
1.5 \mathrm{~m}\end{array}$ & $\begin{array}{l}0.1 \\
0.5\end{array}$ & $\begin{array}{l}\text { LU-4915 } \\
\text { LU-4912 }\end{array}$ & $\begin{array}{l}2970 \pm 70 \\
2230 \pm 70\end{array}$ & $\begin{array}{l}3137 \pm 104 \\
2227 \pm 83\end{array}$ \\
\hline 36 & $\begin{array}{l}\text { River Lena, main chan- } \\
\text { nel, Tit-Ary Island }\end{array}$ & $\begin{array}{l}71^{\circ} 58.382^{\prime} \mathrm{N} \\
127^{\circ} 06.326^{\prime} \mathrm{E}\end{array}$ & $\begin{array}{l}\text { Flood-plain } \\
12-15 \mathrm{~m}\end{array}$ & $\begin{array}{l}5.4 \\
10.7\end{array}$ & $\begin{array}{l}\text { LU-4909 } \\
\text { LU-4918 }\end{array}$ & $\begin{array}{l}4050 \pm 110 \\
830 \pm 70\end{array}$ & $\begin{array}{l}4560 \pm 162 \\
771 \pm 69\end{array}$ \\
\hline 37 & $\begin{array}{l}\text { Trofimovskaya } \\
\text { channel, } \\
\text { Trofim-Diete Island. }\end{array}$ & $\begin{array}{l}72^{\circ} 45.963^{\prime} \mathrm{N} \\
127^{\circ} 56.252^{\prime} \mathrm{E}\end{array}$ & $\begin{array}{l}\text { Alluvial- } \\
\text { estuarine } \\
\text { terrace } 6-7 \mathrm{~m}\end{array}$ & 0.5 & LU-5075 & $1510 \pm 40$ & $1410 \pm 56$ \\
\hline 38 & $\begin{array}{l}\text { Bykovskaya channel, } \\
\text { Lagutin Island }\end{array}$ & & & & $\begin{array}{l}\text { Korotaev } \\
(1984) \\
\text { MGU-773 } \\
\text { MGU-861 }\end{array}$ & $\begin{array}{l}1400 \pm 100 \\
2530 \pm 200\end{array}$ & $\begin{array}{l}1318 \pm 105 \\
2603 \pm 243\end{array}$ \\
\hline 39 & $\begin{array}{l}\text { Olenekskaya channel, } \\
\text { Batyyalakh-Aryta } \\
\text { Island }\end{array}$ & $\begin{array}{l}72^{\circ} 34^{\prime} 52.5^{\prime \prime} \mathrm{N} \\
124^{\circ} 56.027^{\prime \prime} \mathrm{E}\end{array}$ & Terrace $8-10 \mathrm{~m}$ & $\begin{array}{l}0.7 \text { detritus } \\
0.7 \text { wood } \\
7.5 \text { detritus }\end{array}$ & $\begin{array}{l}\text { LU-5497 } \\
\text { LU-5491 } \\
\text { LU-5498 }\end{array}$ & $\begin{array}{l}4800 \pm 80 \\
\text { modern } \\
1961-1981 \\
2700 \pm 70\end{array}$ & $\begin{array}{l}5513 \pm 96 \\
2825 \pm 68\end{array}$ \\
\hline 40 & $\begin{array}{l}\text { Olenekskaya channel, } \\
\text { Dzhangilakh Island }\end{array}$ & $\begin{array}{l}72^{\circ} 30^{\prime} 20.9^{\prime \prime} \mathrm{N} \\
125^{\circ} 17.104^{\prime \prime} \mathrm{E}\end{array}$ & Terrace 9-11 m & $\begin{array}{l}1.5 \\
8.5\end{array}$ & $\begin{array}{l}\text { LU-5494 } \\
\text { LU-5496 }\end{array}$ & $\begin{array}{l}4380 \pm 70 \\
3610 \pm 260\end{array}$ & $\begin{array}{l}5007 \pm 123 \\
3976 \pm 346\end{array}$ \\
\hline
\end{tabular}




\begin{tabular}{|c|c|c|c|c|c|c|c|}
\hline No. & $\begin{array}{l}\text { Location, } \\
\text { channel, island }\end{array}$ & Coordinates & $\begin{array}{l}\text { Geomorphic } \\
\text { position }\end{array}$ & $\begin{array}{l}\text { Height } \\
\text { (m above } \\
\text { water level) }\end{array}$ & $\begin{array}{l}\text { Lab no., } \\
\text { reference }\end{array}$ & C14 age & $\begin{array}{l}\text { C14 age } \\
\text { calibrated }\end{array}$ \\
\hline 41 & $\begin{array}{l}\text { Sardakhskaya channel, } \\
\text { Omsukor-Belkee Island }\end{array}$ & $\begin{array}{l}72^{\circ} 38^{\prime} 16.5^{\prime \prime} \mathrm{N} \\
127^{\circ} 34.280^{\prime \prime} \mathrm{E}\end{array}$ & Terrace $3-4 \mathrm{~m}$ & $\begin{array}{l}2.2 \\
2.7\end{array}$ & $\begin{array}{l}\text { LU-5495 } \\
\text { LU-5492 }\end{array}$ & $\begin{array}{l}3490 \pm 180 \\
880 \pm 60\end{array}$ & $\begin{array}{l}3797 \pm 234 \\
808 \pm 65\end{array}$ \\
\hline 42 & $\begin{array}{l}\text { Bol'shaya Tumatskaya } \\
\text { channel, } \\
\text { Syrdakh Island }\end{array}$ & & $\begin{array}{l}\text { High flood- } \\
\text { plain } 1.6-2.0 \mathrm{~m}\end{array}$ & $\begin{array}{l}0.9 \\
0.5\end{array}$ & $\begin{array}{l}\text { LU-5607 } \\
\text { LU-5608 }\end{array}$ & $\begin{array}{l}950 \pm 50 \\
2590 \pm 70\end{array}$ & $\begin{array}{l}855 \pm 52 \\
2658 \pm 111\end{array}$ \\
\hline 43 & $\begin{array}{l}\text { Bol'shaya Tumatskaya } \\
\text { channel, } \\
\text { Kerdiepime Island. }\end{array}$ & $\begin{array}{l}72^{\circ} 58.889^{\prime} \mathrm{N} \\
126^{\circ} 29.837^{\prime} \mathrm{E}\end{array}$ & $\begin{array}{l}\text { Alluvial- } \\
\text { estuarine } \\
\text { terrace } 5-7 \mathrm{~m}\end{array}$ & $\begin{array}{l}0.7 \\
0.5\end{array}$ & $\begin{array}{l}\text { LU-5610 } \\
\text { LU-5609 }\end{array}$ & $\begin{array}{l}3210 \pm 70 \\
9010 \pm 110\end{array}$ & $\begin{array}{l}3439 \pm 83 \\
10109 \pm 171\end{array}$ \\
\hline 44 & $\begin{array}{l}\text { Osokhtokh channel, } \\
\text { Bezymianny-Oburo } \\
\text { Island }\end{array}$ & $\begin{array}{l}73^{\circ} 06.642^{\prime} \mathrm{N} \\
127^{\circ} 01.159^{\prime} \mathrm{E}\end{array}$ & $\begin{array}{l}\text { Alluvial- } \\
\text { estuarine } \\
\text { terrace } 5-6 \mathrm{~m}\end{array}$ & $\begin{array}{l}4.2 \\
1.3\end{array}$ & $\begin{array}{l}\text { LU-5611 } \\
\text { LU-5612 }\end{array}$ & $\begin{array}{l}2280 \pm 80 \\
3170 \pm 60\end{array}$ & $\begin{array}{l}2288 \pm 123 \\
3389 \pm 75\end{array}$ \\
\hline 45 & $\begin{array}{l}\text { Osokhtokh channel, } \\
\text { Sutura Island }\end{array}$ & $\begin{array}{l}73^{\circ} 10.142^{\prime} \mathrm{N} \\
127^{\circ} 12.271^{\prime} \mathrm{E}\end{array}$ & $\begin{array}{l}\text { Alluvial- } \\
\text { estuarine } \\
\text { terrace } 4-5 \mathrm{~m}\end{array}$ & $\begin{array}{l}2.2 \\
1.2\end{array}$ & $\begin{array}{l}\text { LU-5614 } \\
\text { LU-5613 }\end{array}$ & $\begin{array}{l}2440 \pm 50 \\
4260 \pm 80\end{array}$ & $\begin{array}{l}2527 \pm 107 \\
4802 \pm 131\end{array}$ \\
\hline 46 & $\begin{array}{l}\text { Osokhtokh channel, } \\
\text { Kegeliakh Island }\end{array}$ & $\begin{array}{l}73^{\circ} 20.979^{\prime} \mathrm{N} \\
127^{\circ} 22.520^{\prime} \mathrm{E}\end{array}$ & $\begin{array}{l}\text { Alluvial- } \\
\text { estuarine } \\
\text { terrace } 3-4 \mathrm{~m}\end{array}$ & 2.0 & LU-5605 & $2920 \pm 100$ & $3076 \pm 133$ \\
\hline 47 & $\begin{array}{l}\text { Osokhtokh channel, } \\
\text { Alkhan Island - marine } \\
\text { edge of delta }\end{array}$ & $\begin{array}{l}73^{\circ} 31.546^{\prime} \mathrm{N} \\
127^{\circ} 35.864^{\prime} \mathrm{E}\end{array}$ & $\begin{array}{l}\text { Alluvial- } \\
\text { estuarine } \\
\text { terrace } 1 \mathrm{~m}\end{array}$ & 0.25 & LU-5606 & $540 \pm 80$ & $566 \pm 63$ \\
\hline 48 & $\begin{array}{l}\text { Bykovskaya channel, } \\
\text { Chay-Ary Island }\end{array}$ & $\begin{array}{l}72^{\circ} 24^{\prime} 53.3^{\prime \prime} \mathrm{N} \\
127^{\circ} 27^{\prime} 14^{\prime \prime} \mathrm{E}\end{array}$ & $\begin{array}{l}\text { Alluvial terrace } \\
5 \mathrm{~m}\end{array}$ & 3.7 & KIA-38588 & $>1954$ & \\
\hline 49 & $\begin{array}{l}\text { Bykovskaya channel, } \\
\text { Malsyva Island }\end{array}$ & $\begin{array}{l}72^{\circ} 03^{\prime} 46.1^{\prime \prime} \mathrm{N} \\
128^{\circ} 37^{\prime} 11.7^{\prime \prime} \mathrm{E}\end{array}$ & Terrace, $5 \mathrm{~m}$ & $\begin{array}{l}0.7 \\
1.7 \\
2.3\end{array}$ & $\begin{array}{l}\text { LU-6002 } \\
\text { LU-6003 } \\
\text { LU-6004 }\end{array}$ & $\begin{array}{l}2110 \pm 70 \\
1790 \pm 60 \\
900 \pm 60\end{array}$ & $\begin{array}{l}2104 \pm 103 \\
1714 \pm 77 \\
822 \pm 63\end{array}$ \\
\hline 50 & $\begin{array}{l}\text { Lena river, main chan- } \\
\text { nel, Sordokh-Ary Is- } \\
\text { land }\end{array}$ & $\begin{array}{l}72^{\circ} 22^{\prime} 09.7^{\prime \prime} \mathrm{N} \\
126^{\circ} 31^{\prime} 04.7^{\prime \prime} \mathrm{E}\end{array}$ & $\begin{array}{l}\text { Holocene sedi- } \\
\text { ments boderinf } \\
\text { with ice com- } \\
\text { plex }\end{array}$ & 0.3 & LU-5604 & $3830 \pm 110$ & $4233 \pm 158$ \\
\hline 51 & Olenekskaya channel & & $\begin{array}{l}\text { Alluvial- } \\
\text { estuarine } \\
\text { terrace } 10 \mathrm{~m}\end{array}$ & $\begin{array}{l}9.0 \\
7.0 \\
6.8 \\
6.0 \\
4.9\end{array}$ & $\begin{array}{l}\text { LU-5817 } \\
\text { LU-6006 } \\
\text { LU-6005 } \\
\text { LU-5818 } \\
\text { LU-5819 }\end{array}$ & $\begin{array}{l}2230 \pm 70 \\
2750 \pm 70 \\
3710 \pm 80 \\
2860 \pm 100 \\
3470 \pm 140\end{array}$ & $\begin{array}{l}2227 \pm 83 \\
2867 \pm 75 \\
4065 \pm 119 \\
3007 \pm 128 \\
3758 \pm 179\end{array}$ \\
\hline
\end{tabular}

Peat is fossil fuel assigned to gummites and representing the first stage of plant material transformation as it is converted to coal. It accumulates in swamps from the remains of dead plants subject to partial decomposition under a high humidity and poor access of air. Peat can have a fibrelike structure at a low $(25 \%)$ degree of decomposition and an amorphous structure at a high (50$65 \%)$ decomposition degree. Texture is mostly non-layered. Porosity of peat of a low decomposition degree is very high (70-80\%), and that of strongly decomposed one is usually negligible (Dictionary of Geology, 1973).

The sediments studied in these sections and boreholes differ strongly from peat sediments in several ways:
1. Layering is the most characteristic feature of these sediments and it is clearly pronounced everywhere. It is usually horizontal, but there are also wavy layered sediment sequences. Peat, as defined (Dictionary of Geology, 1973), exhibits little or no layering.

2. Layered sediments show no or very little decomposition of the accumulated plants; this lack of decomposition is not typical for peat. The decomposition degree indicates the content of amorphous matter in peat. Amorphous matter consists of decomposition products of the initial plant matter and very fine tissue fragments which have lost their cellular structure. Depending upon environmental conditions, the degree of decomposition varies from 1 to $70 \%$. Arboraceous and arboraceousherbaceous peat types exhibit the maximum decompo- 

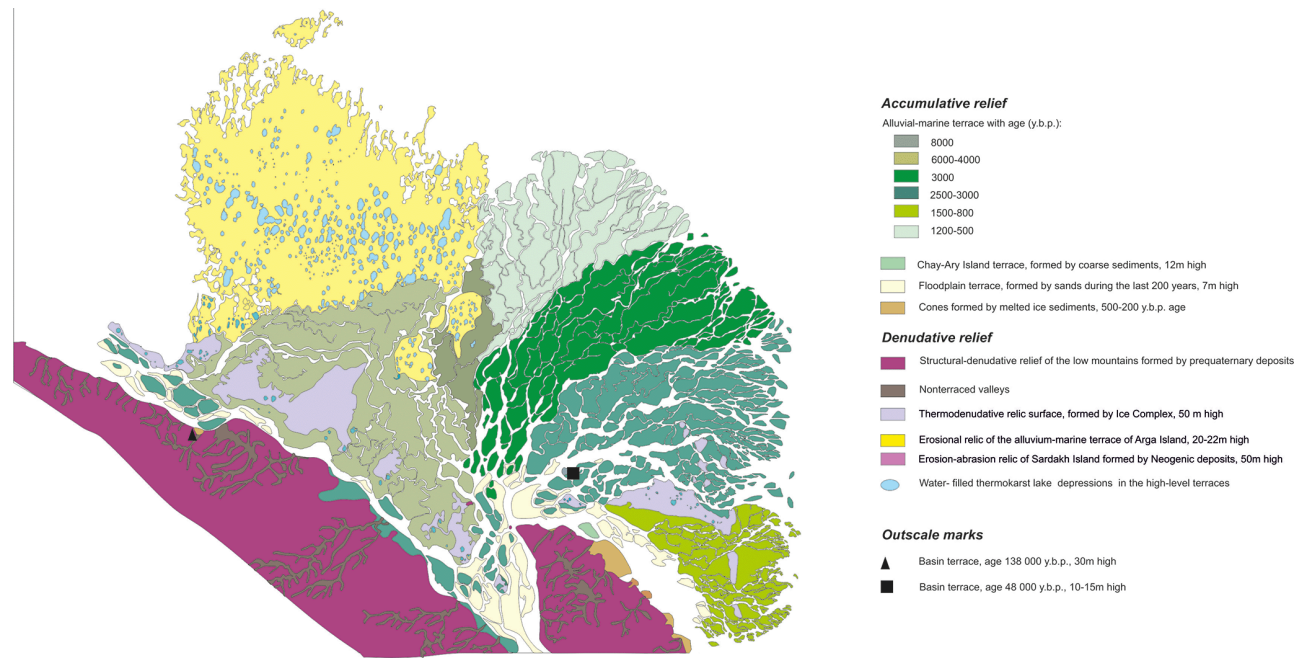

Figure 5. Geomorphic map of the Lena Delta.

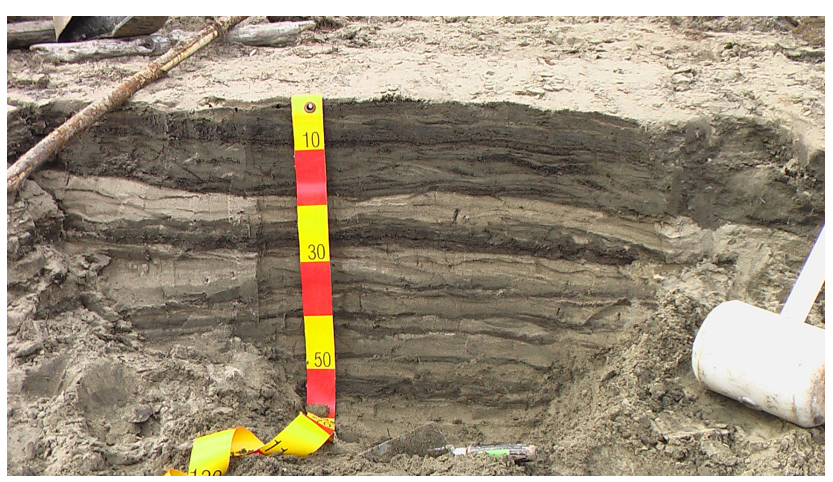

Figure 6. High-floodplain sediments. Samoylov Island.

sition degree, while moss types exhibit the minimum. Under the highest decomposition degree of about $70 \%$ not more than $17 \%$ of initial organic matter is preserved; the remaining $83 \%$ of organic matter is lost due to mineralization to gaseous products and water or from washout. Plant fibre remains account for less than $5 \%$ of the initial organic mass (Lishtvan and Korol, 1975).

3. Organomineral Lena River delta sediments are extremely thick as compared to peat accumulations in northern Yakutia. The maximum recorded thickness of layered sediments composing the first delta terrace is $8 \mathrm{~m}$, and the age of these accumulations ranges from hundreds to 2000 years (the minimum accumulation rate of organic material is $40 \mathrm{~cm}$ in 100 years). According to Skobeyeva and Simakova (1983), peat deposits no more than $1 \mathrm{~m}$ thick rarely form under the harsh conditions of northern Yakutia. Under similar conditions in the Anadyr lowland, Smirnov (1981) points to the impossibility of long-term thick peat deposit formation and also presumes that maximum peat thickness can- not exceed $1 \mathrm{~m}$. In the Kola Peninsula forest zone, peat accumulation rates during the sub-Boreal were $3-8 \mathrm{~cm}$ in 100 years, and slightly later, from 1310 to $1100 \mathrm{BP}$, $18 \mathrm{~cm}$ in 100 years (Pavlova et al., 2005). Peat accumulation rates during the Holocene in the southern taiga of West Siberia ranged from 3.5 to $11.3 \mathrm{~cm} 100 \mathrm{yr}^{-1}$ (Borren et al., 2004) under conditions favourable for peat accumulation. In the zone of severe permafrost in the Lena River delta with a seasonally thawed active soil layer depth of only $30-40 \mathrm{~cm}$, the organic material accumulation rate is 1 or 2 orders of magnitude higher than the known peat accumulation rates in peat deposits of the temperate zone.

4. Under present delta conditions, peat bogs do not form from green mosses in any of the studied water bodies. In numerous drained thermokarst lakes, only a few dozen centimetres of rather well-decomposed plant remains occur, along with mineral material in the form of sand and silt in various proportions.

Thus, referring to the described features of layered sediments, it can be concluded that these organomineral masses did not accumulate in swamps, since the island soils thaw only a few dozen centimetres deep during $\leq 3$ months a year. The age of these layered sediments points to a very recent origin in a period when natural conditions did not differ drastically from modern ones.

Layered sediments are not floodplain sediments. In the modern floodplain with significant river water-level fluctuation amplitudes, the alluvial floodplain facies that are deposited are not at all similar to the organomineral accumulations found on delta islands. Floodplain sediments are characterised by sandy composition, horizontal and cross bedding, and a significant content of plant detritus marking the sediment texture (Fig. 6). The high flow rates that accompany 
high water levels would make any significant deposition of light mosses and plant detritus unlikely.

Horizontal and wavy fibrous textures point to deposition of layered sediments under basin conditions. In more or less stagnant water bodies, where flow rates were not high, mosses, plant detritus, and alternating sands and silts were deposited, indicating flowing water in the deposition basins. Water level fluctuations would be necessary to deposit mosses and sedges that had earlier been flushed from the tundra surface or redeposited from more ancient sections of delta islands. When fluctuating water level conditions (high vs. low tides, surges, floods vs. low water) occur in temporary dewatered squares, plant detritus accumulates at present. Thus, in order to explain past deposition of such sediments, sea-level fluctuations of synoptic scale are required, which are recorded only in the zone of sea basin influence.

The structure of the first Olenek River terrace points to deposition of organomineral sediments in the headwater estuary. At a $100 \mathrm{~km}$ distance from the mouth, layered sediments making up the islands and part of the river banks occur in the lower part of the valley. This area of the river is presently influenced by the sea (Bolshiyanov et al., 2013).

Layered moss sediments are also exposed in a $300 \mathrm{~m} \mathrm{sec}-$ tion along the eastern coast of Ebelyakh Bay (coordinates $72^{\circ} 47^{\prime} 24^{\prime \prime} \mathrm{N}, 140^{\circ} 49^{\prime} 11.5^{\prime \prime}$ E), i.e. on the Laptev Sea coast without modern river influence. These sediments are an outlier of the former thick accumulations of such material under conditions of a basin that was protected from the direct influence of the sea, but maintained a hydraulic connection with the sea. Similar $\leq 15 \mathrm{~m}$ thick accumulations of undecomposed vegetation in modern tundras were described by Tarakanov and Biryukov (1974) in accumulative terraces cut by an erosion scarp in Vankina Bay (Shirokostan Peninsula in the south-western Laptev Sea). These researchers also called these sequences of organogenic deposits peat.

So-called peat bogs are also widespread in the New Siberian Islands. An investigated peat monolith on Kotelny Island (Anisimov, 2010) consisting of undecomposed Hypnum mosses and herbs is $3 \mathrm{~m}$ thick; the age at the top is 3340 and at the base, 5460 radiocarbon years. There are virtually no changes in spore-pollen composition based on analysis of 51 samples which indicates that the sediment sequence was deposited quickly.

Organomineral sediments that are deposited under summer conditions freeze in winter under drain conditions or in a water body under $\leq 2 \mathrm{~m}$ deep ice that reaches the bottom. That is why the first terrace syngenetic massive wedge ice deposits are so widespread and thick. The development of a polygon system with vein ice has been recorded when the water levels of Lake Taimyr are abnormally low, and the polygons are seen under water in its shallow areas. Due to significant water level fluctuations Lake Taimyr also provides an example of massive wedge ice formation under the ice cover which reaches the bottom and persists under a wa- ter layer throughout several summer months (Bolshiyanov 2006).

The source of so much moss vegetation has yet to be elucidated. The green mosses and sedges that dominate the botanical composition of organomineral deltaic deposits were not brought from a long distance away. These are typical tundra plants. These plants might have grown on the surface of vast marshes submerged periodically. The following composition of modern vegetation was described on different Samoylov Island cryogenic polygons (Sachs et al., 2008).

- Polygon 1 (low) with water in the centre: Drepanocladus revolvens (90\%); Carex chordorrhiza (10\%).

- Polygon 2 (high) without water in the centre: Hylocomus splendens ( $85 \%)$; Tomentypnum nitens $(10 \%)$.

- Polygon 3, with a massive ridge and water in the centre, one side of the polygon ridge has crumbled: Drepanocladus revolvens (90\%); Carex chordorrhiza and Carex concolor (10\%). Ridge of polygon 3: Hylocomus splendens (60\%); Rhytidium rugosum (30\%); Carex concolor (4\%).

- Polygon 4 with well-developed ridges, high standing water, and complete isolation from the external water sources feeding the other polygons: Scorpidium scorpidoides (89\%); Carex chordorrhiza (8\%); Carex concolor (3\%).

As can be seen from the above, the composition of modern vegetation is close to that of the fossil deposits found in layered sediments; the vegetation mix is dominated by green mosses and sedges. Commonly, during high water the Lena River carries more tree trunks and small woody and vegetative detritus than mosses and sedges.

The conditions under which the tundra vegetation cover is washed away can occur not only during floods and surges, but as a result of longer-term (dozens to hundreds of years) high levels of the receiving water body. Throughout the last several thousand years, the Lena River delta has been represented by numerous streams and estuaries which were isolated from the receiving water body, because the river and the sea continued to erode significant remnants of land that once existed in the Laptev Sea (Bolshiyanov et al., 2008), particularly in the territory of the modern delta. Backwater from the sea side caused the washout of plant cover from land and its redeposition into the layered sediment sequences. In addition to modern plants, exactly the same green mosses, which are of great importance in the structure of the rock IC, were also incorporated into the newly formed layered sediments. It is the rock IC that composed the islands and land masses in the Laptev Sea which have now disappeared.

Direct evidence of sedimentation under marine conditions is recorded at the edge of the delta in the area of Sagastyr Village (Fig. 2, no. 1), where sediments are salinized and have an age of 1400 years (Schwamborn et al., 2000). 


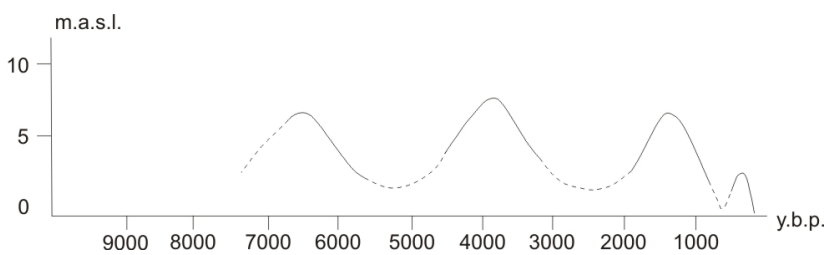

Figure 7. Laptev sea-level fluctuation during the middle and late Holocene.

Thus, the deposits of organomineral masses in the Lena River delta are a record of the Laptev sea-level fluctuations. Numerous radiocarbon dates of these deposits show that the periods of layered sediment accumulation occurred at 8600 , 4500-4000, 2500-1500, and 400-200 BP during Holocene sea-level highstand stages, and sediment washout occurred at 5300 and $500 \mathrm{BP}$. These ages of marine terraces in the Lena River delta region allowed a curve of sea-level fluctuations in this region to be plotted (Fig. 7). At present the period of deposit erosion is coming to an end and Bykovskaya channel is already in an estuary development phase due to the sea level rise on the eastern side of the delta. In the west, in the Olenek channel mouth, sea level decrease continues (Ashik et al., 2010). In accordance with these periods, it was possible to construct a series of palaeo-geographic delta evolution schemes at the close of the late Pleistocene and into the Holocene (Fig. 8).

Around $30000-40000$ BP, the IC accumulation continued, and by the end of this stage significant IC masses had formed along the Primorsky and Chekanov ridges (Bolshiyanov et al., 2008). No evidence has been unearthed to disprove that at $30000-40000 \mathrm{BP}$ the Lena River flowed into the sea in the same place as it does today; thus, the Lena apparently cut through the IC masses as it flowed out from the narrow "Lena tube" caused by a crustal fault in the Earth. From 17000 to $15000 \mathrm{BP}$ the sea level was much lower than it is today, and the river delta or deltas were hundreds of kilometres north of the modern alluvial fan. In place of the modern delta there existed eroded IC rocks. The first layered plant sediments formed in the delta $8000 \mathrm{BP}$ which may indicate an elevated basin stand. During the sea's retreat around 6000 BP the earlier accumulated sediments were eroded, including the IC deposits and the marine alluvial sand mass of Arga-Muora-Sise Island which had been exposed on the surface. At that time, the Lena River apparently acquired the Olenekskaya channel, located along a crustal fault in the Earth, as its main channel. Delta channels again entered an estuary evolution stage at $5000 \mathrm{BP}$, and layered plant sediments accumulated actively at this time. A stage of washout and accumulation of alluvial sands occurred around $4500 \mathrm{BP}$, and around $3500 \mathrm{BP}$ this stage graded into a stage during which the shallow delta estuaries filled with plant material and sandy sediments. A washout stage occurred again from 1000 to $500 \mathrm{BP}$, when IC outliers in the delta assumed their final appearance; the

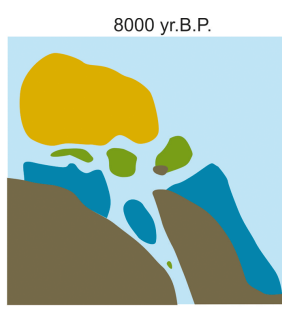

6000 yr.B.P.

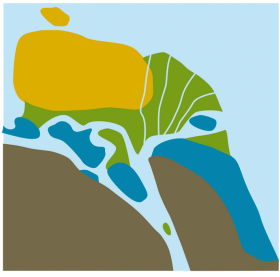

5000 yr.B.P.

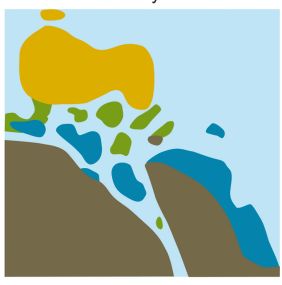

4500 yr.B.P.

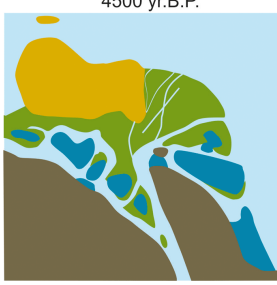

Figure 8. Palaeo-reconstructions of the Lena Delta area.

Bykovskaya channel was formed at the same time. A shortterm sea level rise occurred around $400 \mathrm{BP}$, and then a modern stage of erosion began with another short-term sea level rise around $200 \mathrm{BP}$. Due to tectonic uplifting of the Earth's surface at the delta head the water surface was slanted; as a result the Olenekskaya channel and the central delta channels were cut off from the sea and runoff was redistributed in favour of the eastern and south-eastern delta channels (Bolshiyanov et al., 2013).

\section{Conclusions}

In the Lena River delta, organomineral sediments are extremely widespread and comprise the first alluvial-marine terrace. Results of radiocarbon dating, lithological description, and analysis of spores, pollen, and plant macroremains indicate that these deposits could not have accumulated in floodplain swamps. A layered sediment is a specific sediment type that accumulates under stagnant estuarine conditions when sea level is rising. Since layered sediments accumulated under conditions of high sea level, their dating can show when transgressive phases of delta evolution occurred. 
Geomorphological analysis and compilation of the geomorphological map of the Lena River delta showed that the delta did not form through a simple protrusion into the Laptev Sea. Rather, it evolved by stages under estuarine conditions when it was essentially cut off from the sea; delta formation progressed from west to east during the Holocene. Against this background, sea transgressions occurred during which the organomineral masses accumulated, creating the first terrace. During stages of regression these sediments were partly washed out, as were more ancient islands. Transgressive stages occurred during 8000-6000, 4500-4000, 2500-1500, and 400-200 BP, and periods of sea regression took place at 5300 and $500 \mathrm{BP}$. The regressive periods were shorter than the stages of sea level rise. Currently, the south-eastern part of the delta (Bykovskaya channel) has developed as an estuary under conditions of rising sea level, and the southwestern part (Olenekskaya channel) as a meandering arm under conditions of falling sea level.

Acknowledgements. The authors thank to E. A. Raschke for botanical analysis of peat samples. We are grateful to the Alfred Wegener Institute for Polar and Marine Research (Germany) for the financing the Russian-German "Laptev Sea system" project under which these investigations were conducted. Part of the funds for conducting the research was allocated by the Russian Foundation for Basic Research grant no. 05-05-64419. Great support was given to the authors by the entire Russian-German team of researchers in the course of joint expeditions from 1998 to 2012. However, not all the participants will agree with the interpretation of delta origin proposed here by the authors.

Edited by: P. Overduin

\section{References}

Anisimov, M. A.: Development of natural environment of the New Siberian Islands in Holocene (in Russian), PhD.Thesis, Herzen State Pedagogical University of Russia, 154 pp., 2010.

Arslanov, Kh. A., Tertychnaya, T. V., and Chernov, S. B.: Problems and methods of dating low-activity samples by liquid scintillation counting (in Russian), Radiocarbon, 35, 393-398, 1993.

Ashik, I. M., Makarov, A. S., and Bolshiyanov, D. Yu.: Development of the Russian Arctic coasts related with sea level fluctuations (in Russian), Meteospektr., 2, 23-27, 2010.

Bolshiyanov, D. Yu.: Passive glaciation in the Arctic and in the Antarctica (in Russian), AARI, St. Petersburg, Russia, 296 pp., 2006.

Bolshiyanov, D. Yu., Makarov, A. S., Schneider, V., and Gusev, E. A.: Problems of origin of Ice Complex sediments and existence of "Sannikov's Lands" in the past (in Russian), Problemy Arktiki i Antarktiki, 1, 151-160, 2008.

Bolshiyanov, D. Yu., Makarov, A. S., Schneider, V., and Stoof, G.: Origin and development of the Lena River Delta (in Russian), AARI, St. Petersburg, Russia, 267 pp., 2013.
Borren, W., Bleuten, W., and Lapshina, E.: Holocene peat and carbon accumulation rates in the southern taiga of Western Siberia. Quaternary Res., 61, 42-51, 2004.

Denisenkov, V. A.: Fundamentals of Bog Science: Handbook (in Russian), SPb, Publishing House of SPb Univ., 224 pp., 2000.

Dictionary of Geology (in Russian), Nedra, Moscow, Nedra, V. 2., 320 pp., 1973.

Dombrovskaya, A. V., Koreneva, M. M., and Tyuremnov, S. N.: Atlas of plant residues encountered in peat (in Russian), MoscowLeningrad, 90 pp. and 137 pp. Illustrated, 1959.

Grichuk, V. P. and Zaklinskaya, E. D.: Analysis of pollen and spores and its application in paleogeography (in Russian), Geographgiz, Moscow, 122-123, 1948.

Grigoriev, M. N.: Cryomorphogenesis of the Lena River mouth (in Russian), Yakutsk Institute of Permafrost Studies of the SB RAS, 176 pp., 1993.

Grimm, E. C.: Tilia 1.12, Tilia-Graph 1.18. Illinois State Museum, Research and Collection Center, Springfield, Illinois, 1991.

Gusev, A. I.: Relief of terraces and stages of their development in the Lena River Delta (in Russian), Transactions of NIIGA, Leningrad, 72, 214-223, 1953.

Gusev, A. I.: Quaternary stratigraphy of the Lena-Indigirka coastal plain (in Russian), in: Transactions of Conference of North-East Stratigraphy, Magadan, Russia, 465-468, 1959.

Katz, N. Ya, Katz, S. V., and Skobeeva, E. I.: Atlas of plant residues in peats (in Russian), Moscow, 376 pp., 1977.

Kupriyanova, L. A. and Alyoshina, L. A.: Pollen and spores of plants from the flora of European part of USSR (in Russian), Nauka, Leningrad, 171 pp., 1972.

Kupriyanova, L. A. and Alyoshina, L. A.: Pollen and spores of plants from the flora of European part of USSR (in Russian), Nauka, Leningrad, 184 pp., 1978.

Lishtvan, I. I. and Korol, N. T. : Main properties of peat and methods of their determination (in Russian), Science and Technology, Minsk, 320 pp., 1975.

Makarov, A. S.: Laptev Sea level fluctuations as a factor of the Lena River Delta formation in Holocene (in Russian), Ph.d thesis, Saint-Petersburg State University, faculty of geography, St. Petersburg, Russia, 142 pp., 2009.

Moore, P. D., Webb, J. A., and Collinson, M. E.: Pollen analysis, Blackwell Scientific Publications, Oxford, 216 pp., 1991.

Pavlova, E. Yu., Dorozhkina, M. V., Davydova, N. N., and Denisenkov, V. P.: History of the Ponoi Lake basin (Kola Peninsula) during Middle and Late Holocene (in Russian), in: Ecology of Fresh Water Basins of Russian North, Nauka, St. Petersburg, 169-178, 2005.

Ramsey B., C., Dee, M., Lee, S., Nakagawa, T., and Staff, R. A.: Developments in the calibration and modeling of radiocarbon dates, Radiocarbon, 52, 953-961, 2010.

Reimer, P. J., Bard, E., Bayliss, A., Beck, J. W., Blackwell, P. G., Bronk Ramsey, C., Buck, C. E., Cheng, H., Edwards, R. L., Friedrich, M., Grootes, P. M., Guilderson, T. P., Haflidason, H., Hajdas, I., Hatté, C., Heaton, T. J., Hoffmann, D. L., Hogg, A. G., Hughen, K. A., Kaiser, K. F., Kromer, B., Manning, S. W., Niu, M., Reimer, R. W., Richards, D. A., Scott, E. M., Southon, J. R., Staff, R. A., Turney, C. S. M., and van der Plicht, J.: IntCal13 and Marine13 radiocarbon age calibration curves 0-50,000 years cal BP, Radiocarbon, 55, 1869-1887, 2013. 
Sachs, T., Giebels, M., Wille, Ch., Kutzbach, L., and Boike, J.: Methane emission from Siberian wet polygonal tundra on multiple spatial scales: Vertical flux measurements by closed chambers and eddy covariance, Samoylov Island, Lena River Delta in Proceeding of the 9th International Conference of permafrost, 29 Jun 2008-3 July 2008, Fairbamks,USA, 1549-1554, 2008.

Samoilov, I. V.: River mouths (in Russian), Geografizdat, Moscow, 527 pp., 1952.

Schirrmeister, L., Grosse, G., Schwamborn, G., Andreev, A., Meyer, H., Kunitsky, V., Kuznetsova, T., Dorozhkina, M., Pavlova, Y., Bobrov, A., and Oezen, D.: Late Quaternary history of the accumulation plain north of the Chekanovsky Ridge (Lena Delta, Russia): A multidisciplinary approach, Polar Geogr., 27, 277319,2003
Schwamborn, G., Rachold V., and Grigoriev, M.: Late Quaternary sedimentation history of the Lena Delta, 38 GeoLines, 2000.

Skobeyeva, E. I. and Simakova, L. A.: Peat deposits of Yakutia and their features (in Russian), in: Properties and Methods of Studying Peat and Sapropel Deposits, Kalinin State Univ., Kalinin, 39, 1983.

Smirnov, I. P.: Peat formation in tundra of Amguem Valley and Anadyr Lowland (in Russian), in: Properties and Methods of Studying Peat and Sapropel Deposits, Tver, 4-15, 1981.

Tarakanov, L. V. and Biryukov, V. Yu.: Geomorphological features of modern Laptev Sea ingression in the area of Shirokostan Peninsula (in Russian), Geomorphologiya, no. 4, 98-100, 1974. 